\title{
Metabolit Utama Metilripariokhromen-A, Senyawa Bioaktif dalam Daun Eupatorium Riparium Reg. dalam Urin Tikus Jantan
}

\author{
Major Metabolites of Methylripariochromene-A, a Bioactive Substance in The \\ Leaves of Eupatorium Riparium Reg. in Male Rats Urine
}

\author{
Subagus Wahyuono ${ }^{1,2^{*}}$, Charles S. Vairappan${ }^{1}$, Datin Maryati Mohd. ${ }^{1}$, Vera Fauziati2, \\ Purwantiningsih ${ }^{2}$, Marchaban ${ }^{2}$ \\ 1. Institute of Tropical Biology and Conservation, University of Malaysia Sabah, Malaysia \\ 2. Faculty of Pharmacy, Gadjah Mada University, Yogyakarta \\ Corresponding author: Subagus Wahyuono: Email : subagusw@yahoo.com
}

\begin{abstract}
ABSTRAK
Metilripariokhromene-A (MRC) (1) adalah senyawa bioaktif yang diisolasi dari daun Eupatorium riparium Reg. hasil koleksi Taman Nasional G. Merapi. MRC diisolasi dari ekstrak kloroform daun dengan metoda bioassay (BST) guided isolation. MRC mempunyai efek diuretik, menurunkan tekanan darah, dan mengeluarkan mineral dari tubuh. Efek ini juga ditunjukan oleh furosemide yang secara klinis telah digunakan sebagai diuretik. MRC merupakan senyawa khromen yang mempunyai 2 gugus $-\mathrm{OCH}_{3}$ pada cincin aromatiknya, secara in vivo kemungkinan mengalami demetilasi memberikan gugus fenolik $(-\mathrm{OH})$ yang bersifat antiseptik. Penelitian ini dimaksudkan untuk mengetahui efek diuretik dibandingkan dengan furosemide, mengisolasi dan mengidentifikasi metabolit utama yang terdapat dalam urin, dan kemungkinan MRC dapat digunakan sebagai obat anti-infeksi pada saluran kemih. Ekstrak n-hexana (81\% MRC) $(1,25 \mathrm{~g} / \mathrm{Kg}$ BW) secara per oral diberikan kepada tikus jantan $( \pm 200 \mathrm{~g})$, dan furosemide juga diberikan sebagai kontrol positif untuk diuretik. Urin selama 48 jam dikumpulkan, dipartisi dengan EtOAc selama 15 menit sehingga diperoleh fraksi EtOAc. Fraksi EtOAc difraksinasi, dan metabolit utama yang terdapat dalam fr. 4-5, dan fr. 6-7 dipisahkan dengan KLT preparatif. Identifikasi struktur kimia metabolit utama dilakukan berdasarkan atas data ${ }^{1} \mathrm{H}-$ dan ${ }^{13} \mathrm{C}-\mathrm{NMR}$. Efek diuretik dari ekstrak n-heksana $(1,25 \mathrm{~g} / \mathrm{kg}$ bb) sebanding dengan furosemid $(8,83$ $\mathrm{mL} /$ tikus vs $8,70 \mathrm{~mL} /$ tikus selama 24 jam). Data $1 \mathrm{H}-$ dan 13C-NMR dari fr 4-5 menunjukkan bahwa tidak ada perubahan besar dalam penampilan spektrum 1H- dan 13CNMR dibandingkan dengan MRC, kecuali bahwa gugus 1 -OCH3 didemetilasi menjadi demetil MRC (2) . Berdasarkan eksperimen HMBC dan HMQC, -OCH3 di C-8 adalah yang demetilasi. Data 1H-NMR dari fr. 6-7 mirip dengan fr. 4-5, demetilasi satu-OCH3 grup pada C-8 tetapi hubungan eter dalam sistem ring furan rusak untuk memberikan 2 struktur tentatif (3 dan 4).
\end{abstract}

Kata kunci: Metilripariokhromene-A, urin tikus jantan, metabolit utama

\begin{abstract}
Methylripariochromene-A (MRC) (1) is the principal bioactive compound isolated from Eupatorium riparium Reg. collected from the Mt. Merapi National Park. MRC was isolated from the chloroform extract of the leaves by using bioassay (BST) guided isolation method. MRC causes diuretic, reduces the blood pressure and excretes mineral from the body. This activity is comparable to a clinically used diuretic drug, furosemide. MRC is a
\end{abstract}


chromene type of compound, having $2-\mathrm{OCH}_{3}$ groups on the aromatic ring that are possibly demethylated in vivo to give phenolic compounds well known for having antiseptic properties. This study was aimed to evaluate diuretic properties compared to furosemide, isolate and identify MRC major metabolites present in urine. If it is true, then MRC probably can be used also as anti-infectious diseases in the tractus urinary. n-Hexane extract $(81 \%$ MRC) of E. riparium $(1.25 \mathrm{~g} / \mathrm{kg} \mathrm{bw})$ was applied p.o on male rats $(+200 \mathrm{~g})$ and furosemide was used as a positive control of diuretic activity. Urine was collected during 48 hours, partitioned with EtOAc for 15 minutes to give EtOAc fraction at the upper layer. The EtOAc fraction was then checked by tlc with MRC as the reference standard. The major metabolites were isolated by fractionating the EtOAc fraction followed by purification using preparative tlc (fr. 4-5 and 6-7). The major metabolites obtained were identified based on their ${ }^{1} \mathrm{H}-$ and ${ }^{13} \mathrm{C}$-NMR data. Diuretic effect of $\mathrm{n}$-hexane extract $(1.25 \mathrm{~g} / \mathrm{kg}$ bw) was comparable to furosemide $(8.83 \mathrm{~mL} /$ rat vs $8.70 \mathrm{~mL} /$ rat for 24 hours $)$. The ${ }^{1} \mathrm{H}-$ and ${ }^{13} \mathrm{C}-\mathrm{NMR}$ data of fr $4-5$ indicated that there was not major changing in the ${ }^{1} \mathrm{H}$ - and ${ }^{13} \mathrm{C}-\mathrm{NMR}$ spectra appearance compared to that of $\mathrm{MRC}$, except that $1-\mathrm{OCH}_{3}$ group was demethylated became demethyl MRC (2) . Based on HMBC and HMQC experiments, $-\mathrm{OCH}_{3}$ at $\mathrm{C}-8$ was the one demethylated. The ${ }^{1} \mathrm{H}-\mathrm{NMR}$ data of fr. 6-7 was similar to fr. 4-5, demethylation of one $-\mathrm{OCH}_{3}$ group on $\mathrm{C}-8$ but the ether linkage in the furan ring system was broken to give 2 tentative structures ( 3 and 4).

Keyword: Methylripariochromene-A, urine male rats, major metabolites

\section{INTRODUCTION}

Searching of bioactive compounds has been done in the rain forest of central Kalimantan, Mt. Merapi National Park, Ternate-Halmahera and Batam islands. The bioactive compounds search in TernateHalmahera and Batam islands was emphasized on the presence of CalanolideA in Calophyllum sp. in which calanolide-A was reported present in huge amount at $38 \%$ of latex. Calnolide- $\mathrm{A}$ is a coumarin type of compound having anti HIV virus by inhibiting m-RNA transcriptase enzyme (Subagus et al, 2006). While the search in central Kalimantan and Mt. Merapi National Park was based on the guidance of a local medicine man (Subagus et al, 2004, 2005). There were 130 medicinal plants were collected from central Kalimantan, and only 30 medicinal plants species from Mt. Merapi National Park. Those medicinal plants were dried, pulverized, extracted, and screened by BST (Brine Shrimps Lethality test) at $1000, \quad 500,100,10 \mu \mathrm{g} / \mathrm{mL}$. Twenty medicinal plants collected from central Kalimantan were categorized as potentially high to be studied further and three species were categorized as potentially very-high to be developed further (Subagus et al., 2006). In contrast to the above result, there were only two species out of 30 species collected from Mt. Merapi National Park performed potentially high to be studied further. These were methanol extract of Ficus septica (\# 04-TN 10-13) and chloroform extract of Eupatorium riparium Reg. (\# 04-TN 10-06). The chloroform extract of E. riparium was selected for the study as this extract was more potential (lower $\mathrm{LC}_{50}$ value) than that of F. septica (Nanang et al., 2005).

By bioassay (BST) guided isolation, a bioactive compound was isolated and identified as methylripariochromene-A (MRC) on the basis of its spectroscopic data. MRC displayed $\mathrm{LC}_{50}$ at $4.23 \mu \mathrm{g} / \mathrm{mL}\left(1.6 \times 10^{-}\right.$ 5 M) (Nanang et al., 2007). This value indicated that MRC is valuable enough for further biological study. Indeed this compound was not a new compound and had been isolated in 1969 (Devon and Scott, 1972), but MRC was reported active as hypotensive due to diuretic, vasodilating, 
and decrease cardiac output actions (Matsubara, 1999). As MRC is methyl ether of a phenolic type of compound, it was suspected that MRC would be demethylated in the in vivo to give a free $-\mathrm{OH}$ of phenolic compound that mostly possesses antibacterial activity that would be excreted via urinary tractus. In the future, we expect that MRC displayed hypotensive activity and antiinfective in the urinary tractus as well. So the main aim of this study is to isolate and identify the major metabolites of MRC present in rats urine treated with MRC orally. Instead of pure MRC, standardized extract of E. riparium containing $81 \%$ of MRC was applied orally to rats due to limited amount of pure MRC.

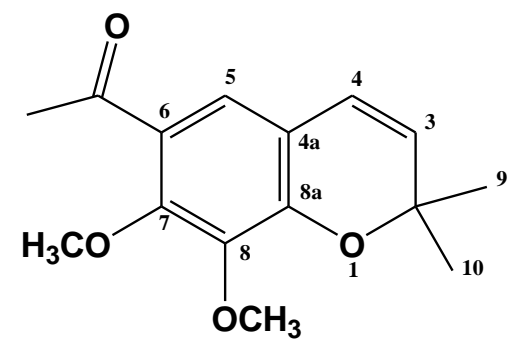

Methylripariochromene-A (MRC) ( $\underline{\mathbf{1}})$<smiles>COc1c(C(C)=O)cc2c(c1O)OC(C)(C)C=C2</smiles><smiles>COc1c(C(C)=O)cc(/C=C\C(C)C)c(O)c1O</smiles>

$\underline{3}$<smiles>COc1c(O)cc(/C=C\C(C)(C)O)cc1C(C)=O</smiles>

$\underline{4}$

\section{METHODOLOGY}

Materials, n-hexane extract of $E$. riparium (collected from Mt. Merapi National Park, consist of $81 \%$ MRC.), Male Rats Wistar strain $( \pm 200$ g), Furosemide ( $0.6 \mathrm{mg} / \mathrm{rat}$, positive control).

Method, MRC treatment. N-hexane extract (80\% MRC) (A) per orally (1.25 $\mathrm{g} / \mathrm{Kg} \mathrm{bw}$ ) was applied to male Wistar-strain rats. The extract was suspended in $0.5 \%$ tween 80 (in water), Urine collection. The urine (B) collected for 24 hours, Metabolites extraction. The urine was partitioned (15 minutes) in a separatory funnel with EtOAc $(50 \mathrm{~mL}, 2 \mathrm{x})$. The EtOAc layers were separated, combined and evaporated to dryness (C). The water layers were combined, evaporated (water-bath) to dry. The residue obtained was triturated with $\mathrm{MeOH}$ to give $\mathrm{MeOH}$ soluble (D) and insoluble fractions (E). MRC (St) was used as a standard. EtOAc fraction (F) of $E$. riparium water extract.

Analysis, Urine volume due to $\mathrm{n}$ hexane extract treatment, compared to control and the structures of the major metabolites were determined by NMR spectroscopy.

\section{RESULTS AND DISCUSSION}

The MRC applied per orally to the rats was replaced by a standardized n-hexane extract of E. riparium leaves contained 81\% of MRC. This step was undertaken as a large 
Table I. Urine collection data

\begin{tabular}{|c|c|c|c|c|c|}
\hline No. & $\begin{array}{c}\text { Dates of urine } \\
\text { Collection }(2008)\end{array}$ & Number of rats & Total urine (mL) & $\begin{array}{c}\text { Urine } \\
(\mathrm{mL}) / \mathrm{rat}\end{array}$ & $\begin{array}{c}\text { Number of } \\
\text { dead Rat }\end{array}$ \\
\hline 1. & $30^{\text {th }}$ Jan & 4 & 42 & 10.5 & - \\
\hline 2. & $31^{\text {st }}$ Jan & 6 & 53 & 8.8 & 1 \\
\hline 3. & $1^{\text {st }} \mathrm{Feb}$ & 4 & 33 & 8.3 & 3 \\
\hline 4. & $4^{\text {th }} \mathrm{Feb}$ & 5 & 45 & 8.1 & - \\
\hline 5. & $5^{\text {th }} \mathrm{Feb}$ & 4 & 33 & 8.3 & - \\
\hline 6. & $6^{\text {th }} \mathrm{Feb}$ & 5 & 50 & 10.0 & 1 \\
\hline 7. & $7^{\text {th }} \mathrm{Feb}$ & 5 & 47 & 9.4 & 1 \\
\hline 8. & $8^{\text {th }} \mathrm{Feb}$ & 4 & 38 & 9.5 & - \\
\hline 9. & $11^{\text {th }} \mathrm{Feb}$ & 4 & 31 & 7.8 & 1 \\
\hline 10. & $12^{\text {th }} \mathrm{Feb}$ & 6 & 56 & 9.3 & - \\
\hline 11. & $13^{\text {th }} \mathrm{Feb}$ & 5 & 44 & 8.8 & 1 \\
\hline 12. & $15^{\text {th }} \mathrm{Feb}$ & 2 & 15 & 7.5 & 1 \\
\hline & Total : & 54 & 487 & 9.02 & $9(16.6 \%)$ \\
\hline
\end{tabular}

amount of isolated MRC was required for this in vivo study $(1.25 \mathrm{~g} / \mathrm{mL} \mathrm{Kg} \mathrm{bw})$. The urines were collected after 24 hours, measured the urine volume and the rats behavior was observed during 24 hours, and no specific behavior was observed during 24 hours; however, 9 rats were found dead (16.6\%) (Table I). Our suspicion about the rats dead was due to dehydration, the water in the cage was practically untouched. Other possibility was that the rats were intoxicated by MRC [ $\mathrm{LC}_{50}$ (BST), $\left.1.6 \times 10^{-5} \mathrm{M}\right]$, in that case lower dose applied should be altered. The diuretic effect of MRC is higher to the clinically used medicine furosemide $(0.6 \mathrm{mg} / \mathrm{rat}) \quad(9.02$ vs 8.7 $\mathrm{mL} /$ rat) (Ernst et al., 1995), and effect of both treatments (furosemide and MRC) are twice higher than that of negative control (3.7 mL/rat) (Table II). The collected urine were combined and partitioned further in order to separate major metabolites according to their polarity (Scheme 1).

Fractions A, C, D, E were subjected on TLC (Thin Layer Chromatography) using selected stationary and mobile phases similar to MRC system. MRC of n-hexane extract was observed at similar rf. value of MRC standard (St.), and there was MRC-like spot present on $\underline{\mathbf{C}}$ except that their rf. values were a bit lower than that of $\underline{\mathbf{S t}}$. While no specific spot was observed on both $\underline{\mathbf{D}}$ and $\underline{\mathbf{E}}$. It meant that MRC major metabolites extraction from the rats urine has completed. In addition, fraction $\underline{\mathbf{F}}$ was prepared in order to see whether MRC present in the water extract or not. This data is very important to be understood as local people use the water extract of the leaves to cure their illness. By a simple detection using TLC picture, the MRC presence in the water extract was detected although MRC known to be fat soluble substance. However, the MRC content in the water extract should be determined. The number of rats dead $(16.6 \%)$ indicated that the dose of MRC consumed possibly too high $[1.013 \mathrm{~g} / \mathrm{Kg}$ bw $(81 \%$ of $1.25 \mathrm{~g} / \mathrm{Kg}$ bw)], although in vivo assay of cranberry proanthocyanidins uses $1.5 \mathrm{~g} / \mathrm{Kg}$ bw (Amy, 2007). In the case of MRC, the dose applied in rats should be lower than $1.013 \mathrm{~g} / \mathrm{Kg} \mathrm{bw}$ in order to have effective dose.

As the $\underline{\mathbf{C}}$ is still showing a complex mixture, the $\underline{\mathbf{C}}$ was then fractionated by VLC (Vacuum Liquid Chromatography) using silica gel to give 10 fractions. Based on the similar appearance to MRC in the TLC 
Table II. Diuretic effect of n-hexane extract of E. riparium

\begin{tabular}{ll}
\hline \multicolumn{1}{c}{ Treatment } & \multicolumn{1}{c}{ Urine volume (mL, after 24 hours) } \\
\hline Control (-) (no treatment) & $3.4,4.2,3.6$ \\
& Average $: 3.7 \mathrm{~mL}$ \\
Control (+) (Furosemide) $(0.6 \mathrm{mg} / \mathrm{rat})$ & $7.6,8.8,9.6$ \\
& Average $: 8.7 \mathrm{~mL}$ \\
MRC $(1.5 \mathrm{~g} / \mathrm{Kg} \mathrm{BW})$ & $487 \mathrm{~mL}$ of $54 \mathrm{rats}$ \\
& Average $: 9.02 \mathrm{~mL}$ \\
\hline
\end{tabular}

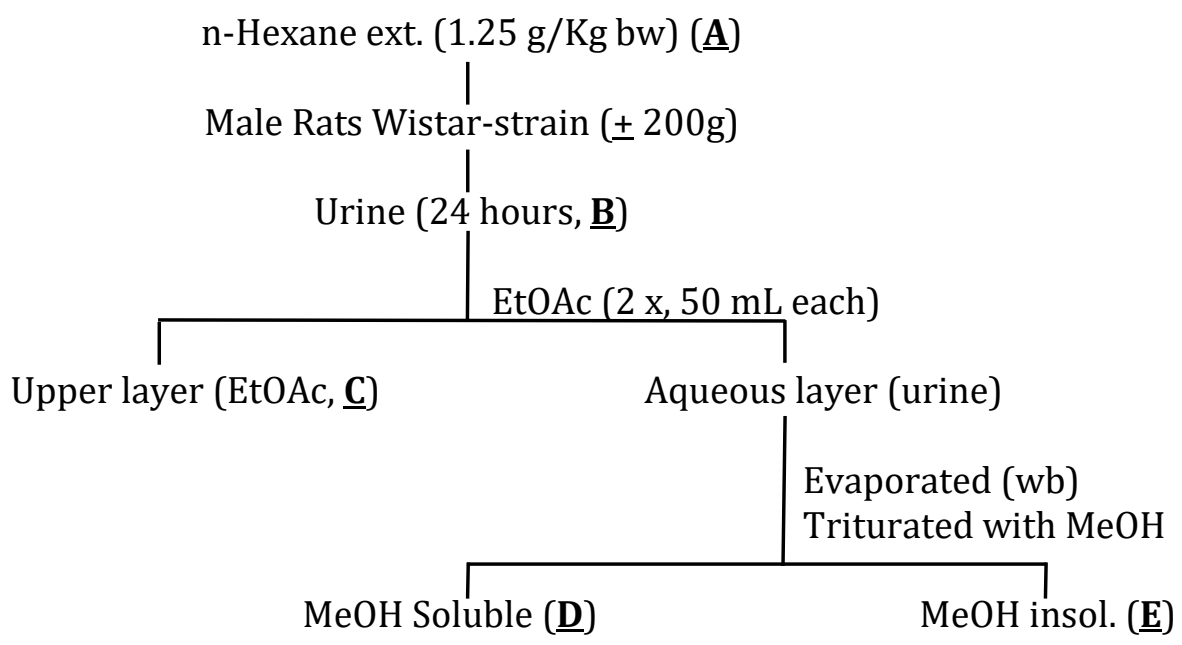

pictures, fractions $4+5$ and $6+7$ were combined separately. Those two combined fractions $(4+5)$ and $(6+7)$ were subjected into preparative TLC for major metabolites purification.

From fraction 4-5, a pure metabolite (TLC) (2) was isolated and the structure was identified by 1 - and 2-D NMR (600 $\mathrm{MHz}$ ) (Umar et al, 2006). According to the ${ }^{13} \mathrm{C}-\mathrm{NMR}$ data (Figure 2), compound 2 carbon signals were very similar to that of MRC (1), except that $1-\mathrm{OCH}_{3}$ was missing. Compound 1 has $2-\mathrm{OCH}_{3}$ groups at $\mathrm{C}-7$ and $\mathrm{C}-8$, now the question arises of which $-\mathrm{OCH}_{3}$ is cleaved to give 2 . The ${ }^{1} \mathrm{H}-\mathrm{NMR}$ of $\mathbf{2}$ (Figure 3) was also similar to that of $\mathbf{1}$, and there was no additional Ar-proton signal. It means that the $-\mathrm{OCH}_{3}$ group cleaved does not produce an $\mathrm{Ar}-\mathrm{H}$, but - $\mathrm{OH}$ (phenolic) group formed instead, that is shown by an additional of broad signal at $\delta, 1.66 \mathrm{ppm}$ in the ${ }^{1} \mathrm{H}-\mathrm{NMR}$ spectra of $\mathbf{2}$ indicating the presence of $-\mathrm{OH}$ group. The structure of 2 (6- acetyl- 7- methoxy- 8- hydroxy -2,2 dimethyl- 2H-1- benzopyran) was deduced using 2D NMR techniques (COSY, HetCor and $\mathrm{HMBC}$ ). The ${ }^{13} \mathrm{C}-\mathrm{NMR}$ and ${ }^{1} \mathrm{H}-\mathrm{NMR}$ (600 $\mathrm{MHz}, \mathrm{CDCl}_{3}$ ) data of $\mathbf{2}$ (Table III and IV) in comparison with $1(100 \mathrm{MHz}$, $\mathrm{CDCl}_{3}$ ).

Based on ${ }^{1} \mathrm{H}-\mathrm{NMR}\left(\mathrm{CDCl}_{3}\right)$ of fr. 6-7 (Figure 4), the isolated compound appeared to be a mixture of $\mathbf{3}$ and $\mathbf{4}$. Similar to $\mathbf{2}$, the ${ }^{1} \mathrm{H}$ NMR spectra showed that only $1-\mathrm{OCH}_{3}$ signal was observed on $\mathbf{3}$ and 4; however, the Ar-H (H-5) was shifted downfield to $\delta$, $7.80 \mathrm{ppm}$ and one of gem-dimethyl shifted downfield to $\delta 1.85 \mathrm{ppm}$. The structures of $\underline{\mathbf{3}}$ and $\underline{\mathbf{4}}$ were deduced tentatively, and further 2D-NMR data were needed to determine their definite structures.

\section{CONCLUSION}

One of the $-\mathrm{OCH}_{3}$ group (C-8) of MRC was de-methylated, and the ether bond of the pyran ring system was cleaved to give metabolite $\mathbf{2}$ and two possible metabolite $\mathbf{3}$ and $\mathbf{4}$ due to cleavage at 


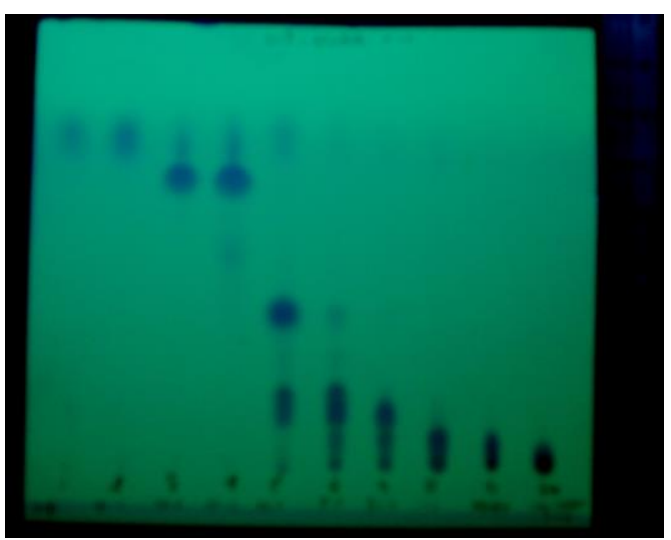

(I)

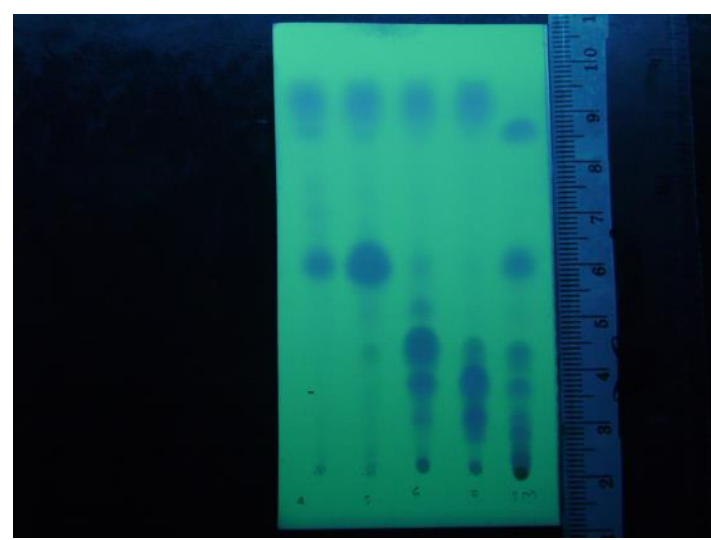

(II)

Figure 1. TLC pictures of fractions obtained from VLC of C (I) [n-hex - EtOAc $(6: 1 \mathrm{v} / \mathrm{v})$ ], and fr. 4-7 and ext. (II) [n-hex - EtOAc $(4: 1 \mathrm{v} / \mathrm{v})]$

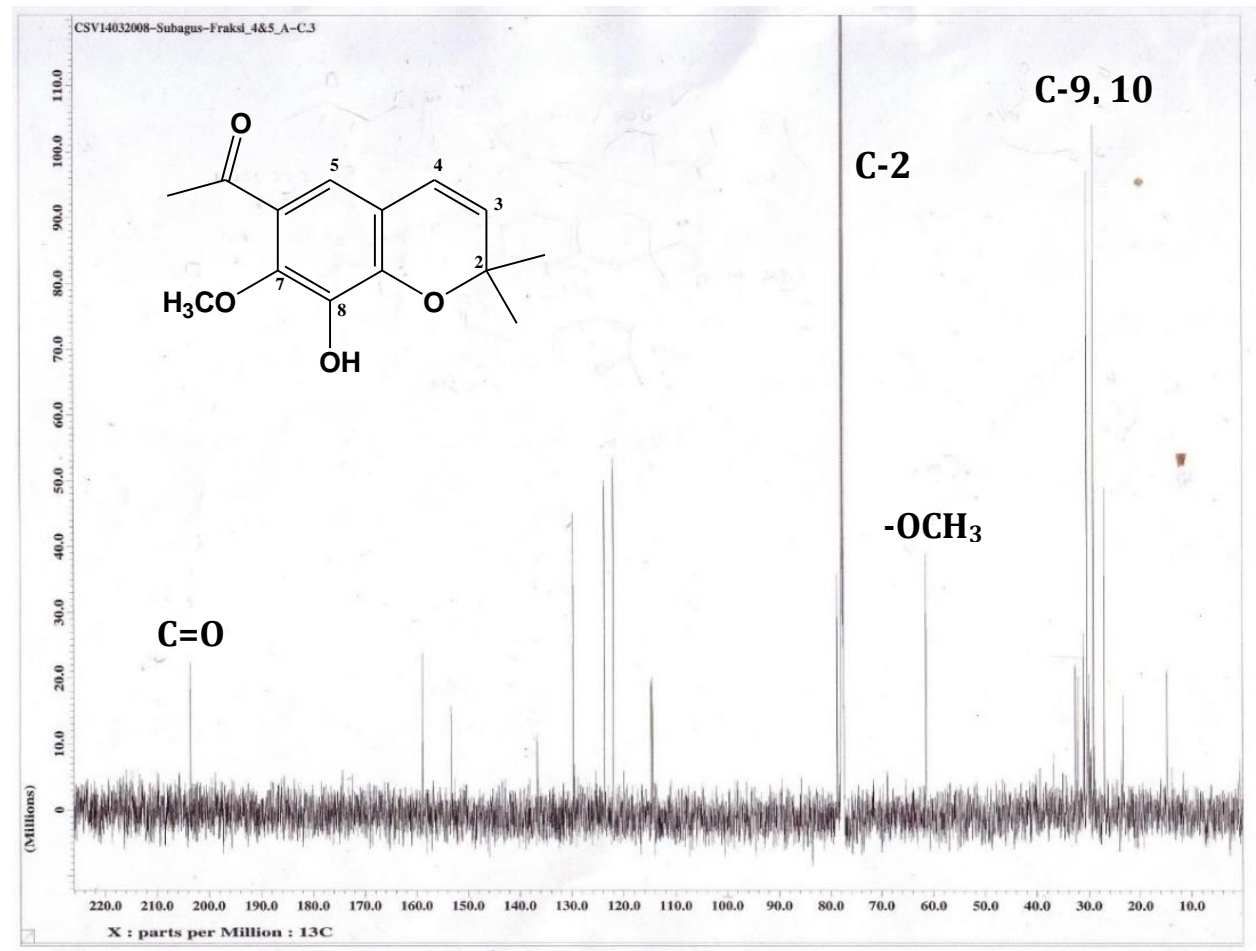

Figure $2 .{ }^{13} \mathrm{C}-\mathrm{NMR}\left(600 \mathrm{MHz}, \mathrm{CDCl}_{3}\right)$ spectra of 2

different bonds. Additional 2D-NMR data are needed to identify two other major metabolites (3 and $\mathbf{4})$. Antiinfective activity of themetabolites on gram $(+)$ and $(-)$ bacteria and fungi should be performed, and it is important to evaluate the benefits of the double actions (diuretic and antimicrobial on urinary tract). 


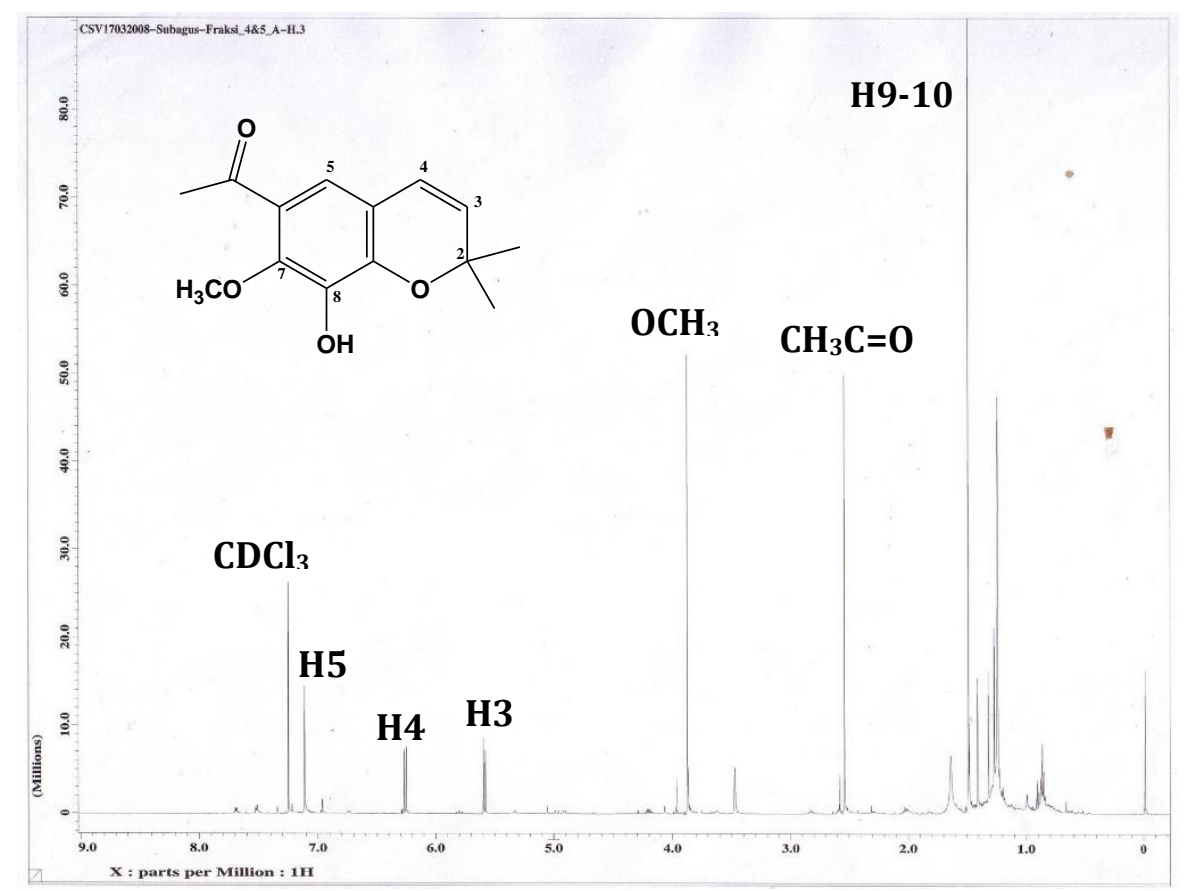

Figure 3. ${ }^{1} \mathrm{H}-\mathrm{NMR}\left(600 \mathrm{MHz}, \mathrm{CDCl}_{3}\right)$ spectra of 2

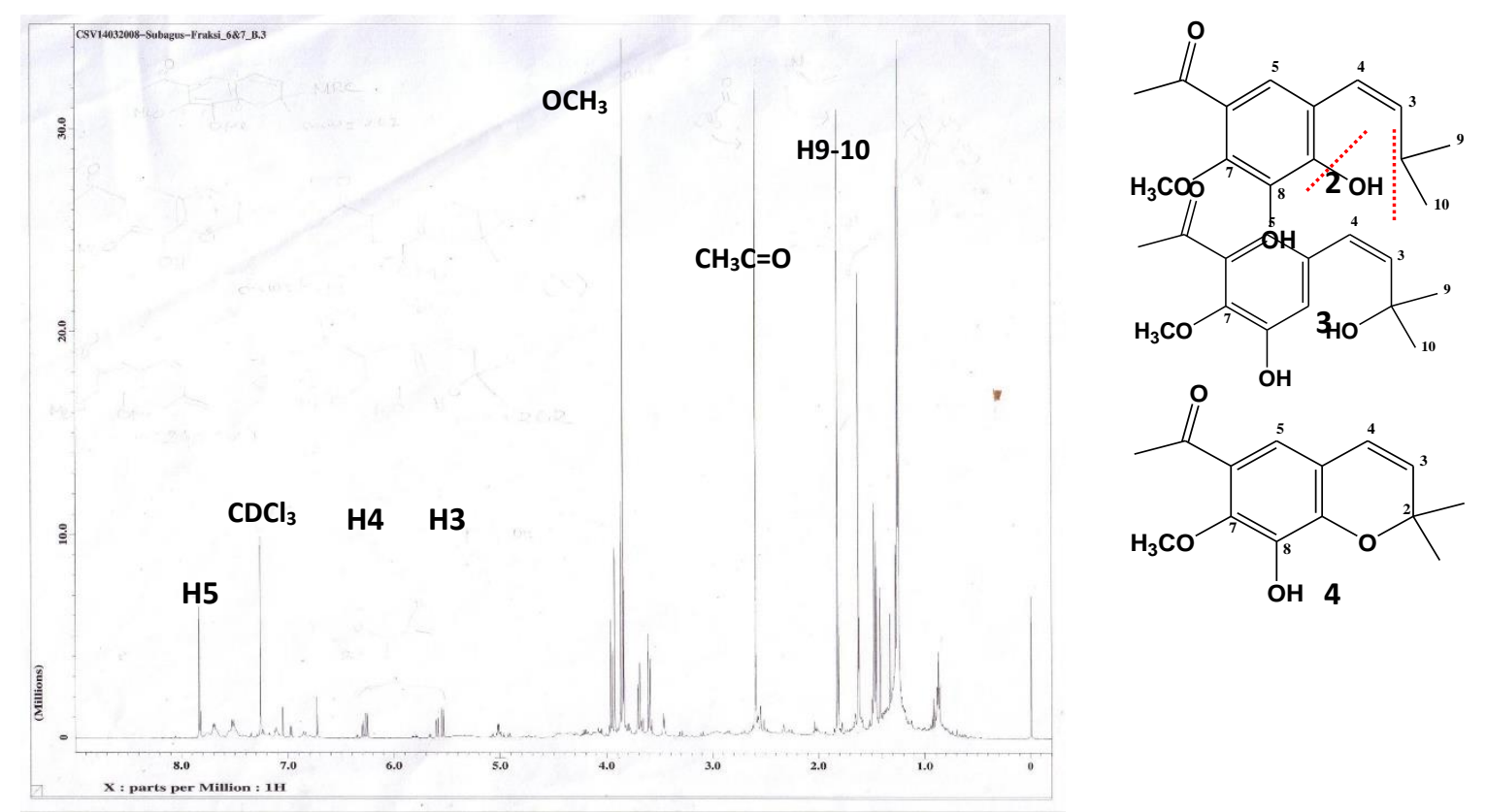

Figure $4 .{ }^{1} \mathrm{H}-\mathrm{NMR}\left(600 \mathrm{MHz}, \mathrm{CDCl}_{3}\right)$ spectra of $\mathbf{3}$ and $\mathbf{4}$ 
Table III. ${ }^{13} \mathrm{C}-\mathrm{NMR}$ data of $\mathbf{1}$ and $\mathbf{2}\left(\mathrm{CDCl}_{3}\right)$

\begin{tabular}{ccc}
\hline- C- & $\boldsymbol{\delta}(\mathbf{p p m}) \mathbf{( 1})(\mathbf{1 0 0} \mathbf{~ M H z})$ & $\boldsymbol{\delta}(\mathbf{p p m}) \mathbf{( 2 )})(\mathbf{6 0 0} \mathbf{M H z})$ \\
\hline 2 & 77.5 & 78.1 \\
3 & 117.6 & 113.9 \\
4 & 121.4 & 114.1 \\
$4 \mathrm{a}$ & 122.1 & 121.4 \\
5 & 129.6 & 129.1 \\
6 & 124.6 & 123.1 \\
7 & 154.3 & 158.2 \\
8 & 141.12 & 136.0 \\
$8 \mathrm{a}$ & 150.6 & 152.6 \\
9 & 28.2 & 28.5 \\
10 & 28.2 & 28.5 \\
$-\mathrm{C}=0$ & 197.4 & 202.9 \\
$-0 \mathrm{OMe}$ & 60.7 & 60.8 \\
$-\mathrm{OMe}$ & 61.3 & - \\
\hline
\end{tabular}

Table IV. ${ }^{1} \mathrm{H}-\mathrm{NMR}$ data of $\mathbf{1}$ and $\mathbf{2}\left(\mathrm{CDCl}_{3}\right)$

\begin{tabular}{ccc}
\hline -H & $\boldsymbol{\delta}(\mathbf{p p m}) \mathbf{( 1 )}(\mathbf{1 0 0} \mathbf{~ M H z})$ & $\boldsymbol{\delta}(\mathbf{p p m})(\underline{\mathbf{2}}) \mathbf{( 6 0 0} \mathbf{~ M H z})$ \\
\hline H-3 & $5.60(d)$ & $5.60(d, 9.7 \mathrm{~Hz})$ \\
H-4 & $6.30(d)$ & $6.30(d, 10.3 \mathrm{~Hz})$ \\
H-5 & $7.22(s)$ & $7.11(s)$ \\
H-9 & $1.49(s)$ & $1.49(s)$ \\
H-10 & $1.49(s)$ & $1.49(s)$ \\
CH3-C=0 & $2.58(s)$ & $2.53(s)$ \\
-OCH3 & $3.88(s)$ & $3.87(s)$ \\
- OCH3 & $3.97(s)$ & - \\
\hline
\end{tabular}

\section{REFERENCES}

Amy B. Howell (2007), Cranberry Proanthocyanidins and Prevention of Bacterial Adhesion. American Society of Pharmacognosy $48^{\text {th }}$ meeting, Portland, Maine, July 14-18

Devon., TK and Scott., AI (1972), Handbook of Naturally Occurring Compounds, volume I; acetogenins, Shikimates and Carbohydrates, Academic Press Inc., New York, p. 267

Ernst Mutschler., Hartmut Derendorf., Monika Schafer-Korting., Karey Elrod., Kerry S. Estes (1995), Basic Principles and Therapeutic Aspects, Medpharm Scientific Publishers, Stuttgart pp. 49, 360.

Matsubara T et al., (1999), Antihypertensive actions of methylripariochromene A from Orthosiphon aristatus, an Indonesian traditional medicinal plant. Biol Pharm Bull; 22: 1083-1088

Nanang Fakhrudin., Subagus Wahyuono., Djoko Santosa (2007), Isolasi dan Identifikasi senyawa bioaktif dari Eupatorium riparium Reg. (\# 04-KU01-06) koleksi dari Taman Nasional Gunung Merapi, Yogyakarta. Majalah Obat Tradisional, vol. 11, no. 40, AprilJuni, hal. 8-14

Nanang Fakhrudin., Subagus Wahyuono., Djoko Santosa., Siti Muslimah Widyastuti (2005), Potensi Bioaktif Beberapa Tumbuhan yang Berasal dari Taman Nasional Gunung Merapi, Yogyakarta, unpublished results. 
Subagus Wahyuono., Siti Muslimah Widyastuti., Djoko Santosa., Soekotjo (2004), Potensi Calophyllum sp. Penghasil calanolide-A dari Maluku utara (Ternate dan Halmahera) dan Kepulauan Riau. Kerjasama antara Fakultas Farmasi-Kehutanan UGM dengan Departemen Kehutanan RI serta Otorita Batam.

Subagus Wahyuono., Soekotjo., S. M. Widyastuti., Joko Santosa (2004). Koleksi Tumbuhan Obat di Bukit Baka Kalimantan Tengah, Kerjasama antara Fakultas Farmasi - Kehutanan UGM dengan Balai Konservasi Sumber Daya Alam (KSDA) Yogyakarta, melalui pendanaan Dept. Kehutanan RI.
Subagus Wahyuono., Jusain Setiadi., Djoko Santosa., Mae Sri Hartati W., Soekotjo., S. M. Widyastuti., 2006, Potential bioactive compound isolated from akar kuning (Fibraurea chloroleuca Miers.) collected from central Kalimantan rain-forest as anticancer, Majalah Obat Tradisional, Vol. 11, no.36, April-June, 22-28.

Umar A. Jenie., Leonardus B. S. Kardono., Muhammad Hanafi., Rymond J. Rumampuk., Akhmad Darmawan (2006), Teknik Modern Spektroskopi NMR, Teori dan Aplikasi dalam Elusidasi Struktur Molekul Organik dan Biomolekul, volume 1. Lembaga Ilmu Pengetahuan Indonesia (LIPI), Jakarta. 